Ethiopian Journal of Environmental Studies \& Management 8(Suppl. 1): 782 - 791, 2015.

ISSN:1998-0507

doi: http://dx.doi.org/10.4314/ejesm.v8i1.5S

Submitted: May 28, 2015

Accepted: September 23, 2015

\title{
DETERMINANTS AND EFFECT OF LIVELIHOOD DIVERSIFICATION AMONG SMALL- SCALE POULTRY FARMERS IN OYO STATE, NIGERIA
}

\author{
*BABATUNDE, R.0., AYINDE, 0.E., OLADIP0, F.0. AND ADEKUNLE, A.0. \\ Department of Agricultural Economics and Farm Management, University of Ilorin, Ilorin, \\ Nigeria
}

\begin{abstract}
Promotion of rural income diversification continues to gain widespread support in poverty reduction strategy discourse in the developing countries. This study examined diversification of rural livelihood among small-scale poultry farmers in Oyo state, Nigeria. The study utilized data from a sampled survey of 104 small-scale poultry farming households to establish the effect of diversification of livelihood on poultry production and factors determining diversification of income among the poultry farmers in the study area. Results showed that majority of the farmers are male, married, and young with mean age of 44.35 years. The average year of schooling of the farmers was 10.3 years and mean farming experience is 7.52 years. Approximately $46 \%$ of the farmers have access to credit and $44.2 \%$ are member of cooperative society. The results showed that, at the $1 \%$ level, there is significant difference between farm size of farmers with other sources of income and the farmers without any other source of income. Farm size is significantly and positively related to non-poultry income, education and farming experience among the smallholder poultry farmers at 10\% level of significance. The major determinant of livelihood diversification includes education level of households head, household size, access to credit and cooperative society membership.
\end{abstract}

Key Words: Diversification, small-scale, poultry farmers, multinomial, logit, regression.

\section{Introduction}

In the last three decades many countries of the world have struggled with policies and programs that will reduce this problem to minimum level and concrete solution has not yet been found as the poverty level is on the increase. Worldwide, the rural communities harbour the larger majority of the poor, likely accounting for more than $70 \%$ of the total population (World Bank, 1999). Hence, the debate on the relationship between small farms and poverty in Sub-Saharan Africa (SSA) has gone through a complete circle (Spencer, 2002; Poulton et al., 2005; Lipton, 2005).
Successive governments in Nigeria have repeatedly adopted policies and programs on virtually every aspect of the national life that would reduce poverty. Programs intended to ensure food selfsufficiency and provide necessary infrastructure to stimulate economic growth, enhance incomes and improve the welfare of the poor. Also, tremendous efforts were made to improve agricultural production and living standards through public credit institutions like Nigerian Agricultural Cooperative and Rural Development Bank (NACRDB) transformed to Agricultural Bank of Nigeria (NAB)and more recent programs 
like National Fadama Development project (NFDP), Community based Poverty Reduction Project (CPRP), Local Empowerment and Environmental Management Project and Community and Social Development Project (CSDP which upshot from LEEMP and CPRP) (Idowu et al., 2011a). Furthermore, in an attempt to provide formal insurance cover for the financial risk associated with agricultural enterprises, the Nigerian Agricultural Insurance Company (NAIC) was established in 1989 (Adekunle et al., 2012).

Livestock are ubiquitous in poor communities across the developing world. An estimated two-thirds of resource-poor rural households keep some type of livestock (LID, 1999). Animal husbandry is one of the major means of livelihood in the rural Nigeria, especially poultry keeping. Similar information for poor urban households is scarce, but a recent survey in two cities in Nigeria found that more than one-half of all urban households were keeping livestock; the highest rates were found in the most densely populated, lower-income areas (Randolph et al., 2011). According to Kazybayeva et al., (2006) FAO, (2007) Nouala, (2011), livestock plays many important roles, including: as a provider of employment to farmer and family members; as a form of insurance; as a store of wealth; contributing to gender equality by generating opportunities for women; recycling waste products and residues from cropping or agro industries; improving the structure and fertility of soil; and controlling insects and weed. Livestock residues can also serve as an energy source for cooking, contributing to food security (Gueye, 2009).

Ellis (2000), Barrett (2001) stated that livelihood concept and diversification of income among rural households help in alleviating poverty. It is generally believed that non-farm income activities play an enormous role in poverty alleviation because non-farm income can significantly increase the total income of rural dwellers, help smooth out income fluctuations, and improve food security through savings, which in turn allows rural dwellers to survive sudden shocks (Omilola, 2009).

One important pathway toward sustainability of livelihoods involves avoidance of long term dependency on only one income source (Block and Webb, 2001). The livelihood portfolio is the bundle of activities households engage in to generate livelihood and achieve a certain level of livelihood security (Rudie, 1995), while diversification of income sources has been put forward as one of the strategies households employ to minimize household income variability and to ensure a minimum level of income. Livelihood diversification is the process by which rural households constructs an increasingly diverse portfolio of activities and assets in order to survive and improve their standard of living' (Ellis, 2007 and Scoones, 1998). Livelihood diversification therefore refers to attempts by individuals and households to find new ways to raise incomes and reduce environmental risk, which differ sharply by the degree of freedom of choice (to diversify or not), and the reversibility of the outcome (Adugna, 2012). Reardon et al. (2001) and Idowu, et al. (2011b) reported that the contribution of non-farm income sources to the rural economy has grown substantially during the last two decades and different country case studies illustrate that the share of non-farm income to total household income ranges between about $30 \%$ and $40 \%$ while Islam (1997) reports that the share of the non-farm sector in rural employment in developing countries varies from $20 \%$ to $50 \%$. Reardon (1997) finds rural non-farm income shares in Africa ranging from $22 \%$ to $93 \%$.

The diversification of livelihoods can either offer opportunities for farmers or, if 
not properly managed, add to the pressures on them. Research shows that while some forms of diversification enhance welfare, others can increase risk. Poultry farmers are diversifying, but their capacity is limited and reflective of their inherent skills and knowledge. Diversification of income sources, assets, and occupations is the norm for individuals or households in different economies, but for different reasons. According to Babatunde and Qaim, (2009); Reardon (1997) household can diversify sources of income to increase income when the resources needed for the main activity is too limited to provide a sufficient livelihood, to reduce income risks in the face of missing insurance market, and to exploit strategic complementary and positive interactions between different activities.

Income diversification, generally in the rural Nigeria is very well known and has been widely documented. For instance (Babatunde and Qaim, 2009; Oluwatayo, 2009) opined that Nigerians diversify their livelihood strategies, including on-farm (crop, livestock, fisheries) and off-farm activities or market and non-market activities, to mitigate risks inherent in unpredictable agro climatic and politico economic circumstances. Few studies have addressed the impacts of non-farm income on household farm activities in general and specifically among the livestock producers.

This study therefore focuses on income diversification among the small-scale poultry producers and the implication on poultry production in Oyo State, Nigeria. The specific objectives are to determine the effect of non-poultry income on smallscale poultry production, and determine the factors responsible for income diversification among the small-scale poultry farmers in the study area.

Knowledge of socio-economic characteristics, effects of non-poultry activities and their contribution to poultry production could be of great value for policy makers in designing anti-poverty strategies in Nigeria. This study could also provide information that could assist the rural dwellers to diversify their income activities to mitigate the effect of poverty. The paper can also contribute to the existing literatures on the economies of poultry production and rural livelihood diversification.

\section{Methodology}

This work utilizes data collected in a survey of 104 small-holder poultry farmers selected from five local government areas of Oyo State. These are Afijio, Atiba, Iseyin, Oyo East and Oyo West; this is due to the relative concentration of small-scale poultry production in the area. The respondents were randomly selected from the lists of Poultry Farmers of Nigeria in the State. The state has a total population of about 5.6 million and covers a total of $27,249 \mathrm{~km}^{2}$ of land mass. Majority of the smallholder farmers are living in the rural areas (NPC, 2006).

The data were collected in 2012, using interview guide with structured questionnaire. A two-stage simple random sampling technique was used to select the sample for the study. The first stage involved the random selection of five Local Government Areas in the state. The second stage involved the random selection of 104 small scale poultry producers. Efforts were made to collect the lists of poultry farmers from Poultry Association of Nigeria in the study area. The lists were stratified into three strata namely small, medium and large scales. The small-scale stratum was chosen for random selection of the respondents. In the second stage of data selection, the smallscale poultry farming households were selected by simple random selection method. Ikheloa and Inedia (2005) classified poultry farm size of 1-999 birds as a small-scale, 1000-2999 as a mediumscale and 3000 and above as a large scale. 
Information on socio-economic characteristics of smallholder poultry farmers, inputs and outputs, as well as management practices in poultry production were collected.

To determine the effects of non-poultry income on poultry production, the comparative analysis of the farm size between the poultry farmers with and without other sources of income was modelled using z-test or difference of means. Determinant of farm size was modelled using ordinary least squares (OLS) regression method and determinant of diversification of income was modelled using multinomial logistic regression method.

\section{Analytical Technique}

Descriptive analysis was carried out with the use of descriptive statistics such as frequency table and percentages to determine socioeconomic characteristics of the respondents. Difference of means was used to compare the farm size which is the proxy for poverty reduction, of the poultry farmers with other sources of income and poultry farmers without any other source of income. Difference of means was computed to test for the significant difference between the farm sizes of two categories of farmers. Z-test was used and calculated with the formula below to analyze if there is any difference in farm sizes between the two categories of respondents. The Multinomial logistic regression was used to estimate the determinants of diversification among the farmers (Bayaga, 2010).

\section{Results and Discussion}

\section{Socio-economic Characteristics of Respondents}

The descriptive statistics were used to determine the socio-economic characteristics of the respondents obtained, they include gender, marital status, household size, education level, age, cooperative society membership, farming experience, farm size and credit accessibility.

Table 1 shows that majority of the small-scale poultry operators are male, 86.5 percent with few female. This may be due to the high risks involved in poultry business and women are not good risk takers as observed by Ironkwe and Ajayi (2007). The result also shows the household size of the respondents, table 1 shows the mean to be 5.45. The household compositions of the respondents include husband/wives, children and other dependents. This suggests that, other things being equal, family labour is likely to be available, in the study area. The size of the family can determine the availability of family labour on the farm. The result reveals that the majority of the smallholder poultry operators have formal education. The level of education includes HND/ND, NCE, and bachelor degree, and table 1 reveals that the mean is 10.29 . The high levels of education would contribute to their ability for efficient resource management in their business. It could also positively affect the farmers' access to useful information that may help them increase their productivity.

Table 1 also shows the age of the respondents, the mean age of the respondent is 44.35 years. This means that the majority of the respondents are middle age farmers, with their mean age of 44.35 years old. They are relatively young and fall within the active age bracket. They belong to economically active population category which is between 25-59 years according to FAO (1997). The table also presents the farming experience of the respondents showing mean farming experience as 7.52 years. The level of experience would contribute to their ability for efficient resource management in their business. Farming experience could also relate to the acquisition of good skills in the use of any technological innovation. 
Table 1: Descriptive statistics

\begin{tabular}{|c|c|c|c|}
\hline Variables & Description & Mean & Std. dev. \\
\hline Household size & Total number of individuals comprise of a family & 5.45 & 2.149 \\
\hline Gender & Sex of the head of the poultry farming household & 0.86 & 0.342 \\
\hline Age & Age of the individual household heads & 44.35 & 10.38 \\
\hline $\begin{array}{l}\text { Farming } \\
\text { experience }\end{array}$ & Total number of years so far spent in poultry production & 7.51 & 4.45 \\
\hline Farm size & $\begin{array}{l}\text { Number of birds that are kept by each poultry farming } \\
\text { household }\end{array}$ & 405.4 & 269.8 \\
\hline $\begin{array}{l}\text { Access } \\
\text { credit }\end{array}$ & $\begin{array}{c}\text { This is an indication that a poultry farmer has } \\
0.500\end{array}$ & 0.461 & 0.500 \\
\hline $\begin{array}{l}\text { Cooperative } \\
\text { membership }\end{array}$ & $\begin{array}{l}\text { accessed credit from any source for poultry business. } \\
\text { This is to indicate whether a poultry farmer belong } \\
\text { to a cooperative society or not. }\end{array}$ & 0.442 & 0.499 \\
\hline Education & $\begin{array}{l}\text { Level of education attained by poultry farming household } \\
\text { heads }\end{array}$ & 10.29 & 5.486 \\
\hline Diversification & $\begin{array}{l}\text { Number of sources or investments through which an } \\
\text { individual can generate income }\end{array}$ & 0.365 & 0.483 \\
\hline
\end{tabular}

Table 1 also shows the age of the respondents, the mean age of the respondent is 44.35 years. This means that the majority of the respondents are middle age farmers, with their mean age of 44.35 years old. They are relatively young and fall within the active age bracket. They belong to economically active population category which is between 25-59 years according to FAO (1997). The table also presents the farming experience of the respondents showing mean farming experience as 7.52 years. The level of experience would contribute to their ability for efficient resource management in their business. Farming experience could also relate to the acquisition of good skills in the use of any technological innovation.

The result reveals that minority of the respondent have access to credit for their poultry activities at a time or the other, the credit sources include Agricultural bank, commercial banks cooperative societies microfinance banks and relatives. The result also shows that minority of the respondents $(44.2 \%)$ belong to other cooperative societies apart from being a member of poultry farmers association
(PAN). This implies that they have other means to access credit, sell their products or purchase inputs in bulk and obtaining information on their business, these can also reduce the total cost of operation.

The respondent farmers raise pullets for eggs production, broiler and cockerel for meat. Majority of them operate on deep litter while few operate on battery cage systems with mean farm size of 405 birds. This is an indication of low levels of technology and production, which are also the characteristics of most farmers in the study area. The members of the farming households contribute family labour to production activities on the farm to complement hired labour, which is also used. The result shows that minority of the respondent farmers have other income activities apart from poultry production. The mean for diversification of income activities is 0.3654 which is $36.54 \%$. This implies that many of the small-scale poultry farmers did not diversify their income sources which are not good for a household during the period of financial shock. 
Farm size of the poultry farmers with and without other sources of income

In order to compare the farm size between the small-scale poultry farmers with other sources of income and those without other sources of income, difference of means was used. Difference of means was computed to test for the significant difference between the farm sizes of the farmers with and without other sources of income.

Table 2: Difference of means of farm size

\begin{tabular}{llll}
\hline Farm size & & Category 1 & Category 2 \\
\hline & Mean & 590.55 & 298.82 \\
& SD & 286.49 & 192.51 \\
& Observation & 38 & 66 \\
\hline$Z$
\end{tabular}

Z- Statistic $($ cal. $)=5.592$, Z- critical $($ tab $)$ two tailed $=2.626$, Level of significance $=1 \%$

\section{Hypothesis Testing: Two Tail Test}

Null hypothesis: $\mathrm{H}_{0}$ : There is no significant difference between the farm size of the small-scale poultry farmers with other sources of income and those without other sources of income i.e. $\mathrm{H}_{0}: \mathrm{U}_{1}=\mathrm{U}_{2}$

Alternative Hypothesis: $\mathrm{H}_{\mathrm{A}}$ : There is significant difference between the farm size of the small-scale poultry farmers with other sources of income and those without other sources of income i.e. $\mathrm{U}_{1} \neq \mathrm{U}_{2}$

If $\mathrm{Z}-$ cal $>$ Z-tab: reject $\left(\mathrm{H}_{\mathrm{o}}\right)$ null hypothesis and accept alternative hypothesis $\left(\mathrm{H}_{\mathrm{A}}\right)$

If $\mathrm{Z}-\mathrm{cal}<\mathrm{Z}$ - tab: accept $\left(\mathrm{H}_{\mathrm{o}}\right)$ null hypothesis

The above $\mathrm{Z}$ - test shows that at $1 \%$ level of significance, $Z$ - cal is greater than Z-tab. Therefore, the alternative hypothesis $\left(\mathrm{H}_{\mathrm{A}}\right)$ that states that there is significant difference between the farm size of the small-scale poultry farmers with other sources of income and those without other sources of income is accepted whereas the null hypothesis is thus rejected, meaning that, there is significant difference between the farm size of the small-scale poultry farmers with other sources of income and those without other sources of income. This implies that the income received from other sources has significant effect on their level of production, that it significantly increased their scale of production. It can be due to the ability of the poultry farmers with other sources of income to re-invest that extra-income to boost their scale of production. They have other occupations which they are engaged, they finance their farms from the money realized from these occupations. By these reasons the farm size of the small-scale poultry farmers with other sources of income and those without other sources of income could be significantly different.

\section{Determinants of Farm Size}

In this section, we analyze the determinants of farm sizes among the sampled small-scale poultry producers. We carried out an Ordinary Least Squares regression analysis to model the farm size in head as a function of non-poultry income, household size, farming experience gender and the education level of the household head. The regression estimate is shown in table 3 .

The Linear production function was chosen as the lead equation. It was based on the significance of individual explanatory variables as expressed by their $\mathrm{t}$-values and the appropriateness of the sign of regression coefficient based on a priori expectation. The magnitude of the coefficient of multiple determinations $\left(\mathrm{R}^{2}\right)$ and the significance of the overall production function as judged by the $\mathrm{f}$ value. The $\left(R^{2}\right)$ of the fitted function is 
0.272.This indicates in the function that the explanatory variables explained $27.2 \%$ of the variation in the farm size of poultry production.

Table 3: OLS estimates of determinants of farm size

\begin{tabular}{|c|c|c|}
\hline Variables & Coefficient & t-value \\
\hline Non-poultry income ( & $0.188^{*}$ & 1.878 \\
\hline Household size & 0.045 & 0.504 \\
\hline Gender of the household head $($ male $=1$, female $=0$ ) & 0.012 & 0.141 \\
\hline Education (Year) & $0.266 * * *$ & 2.750 \\
\hline Farming experience (year) & $0.242 * * *$ & 2.641 \\
\hline Constant & 95.514 & 0.976 \\
\hline $\mathrm{R}^{2}$ & 0.272 & \\
\hline F-value & 7.341 & \\
\hline
\end{tabular}

Note: Dependent variable is the farm size of small-scale poultry farm in heads of animal $*, * * *$, indicate coefficient significant at 10 and $1 \%$ level respectively.

From the lead equation, the coefficients of all explanatory variables are positive conforming to a priori expectation. The result from the lead equation also shows that income from other sources apart from poultry $\left(\mathrm{Y}_{\mathrm{NP}}\right)$ is significant at $10 \%$ level of significance. A $1 \%$ increase in non-poultry income will increase the farm size by $0.19 \%$.Education of the household head $\left(\mathrm{EDU}_{\mathrm{HD}}\right)$ and farming experience (FME) are significant at 1 percent level of significance each meaning that, $1 \%$ increase in the level of education and farming experience will increase farm size by $0.27 \%$ and $0.24 \%$ respectively. This indicates that non-poultry income has a positive impact on poultry farm size. This could be so, because the farmers would have more cash to invest in poultry production and boost their production and lead to increase in household income. The level of significance of education shows the importance of education in poultry production, this could help the farmers adopt better technology and acquire better skills. Therefore, these can increase the farm size and transfer to the household income. Farming experience afford the farmers of gaining better knowledge of the production and could result into efficient resources management and improved production. However, since the F-value i.e. an overall test of significance of the function was significant at 1percent level, non-significance of an individual regression coefficient could be permitted to a certain extent.

Determinant of Diversification of Income among Poultry Farmers

In this section, we analyzed the factors responsible for diversification of income sources among the sampled small-scale poultry households. Multinomial logistic regression analysis was modelled to carry out the analysis of factors determining diversification of income in the study area.

Table 4 presents the marginal effects along with the levels of statistical significance. Education of the household head is positive and statistically significant at $1 \%$ level of probability meaning that it increases the probability of diversifying income sources. As observed in Table 4, a unit increase in number of years of schooling would result in $56.5 \%$ increase in the probability of income diversification. The result also shows that household size is positively and statistically significant at $10 \%$ level of probability meaning that it increases the likelihood of diversifying the means of livelihood. It shows that a unit increase in 
household size would lead to $67.3 \%$ increase in the probability of income diversification. Table 4 shows that access to credit is significantly positive at $1 \%$ level of probability, this indicates that a unit increase in credit accessibility would lead to $56.9 \%$ increase the probability of income diversification. The result also shows that cooperative membership is significantly positive at $1 \%$ level of probability; this indicates that a unit increase in cooperative society's participation would lead to $32.6 \%$ increase the likelihood of influencing incomegenerating activities diversification in the study area.

Table 4: Multinomial logistic regression of the determinants of livelihood diversification

\begin{tabular}{|c|c|c|}
\hline Variables & Marginal effect & Std. Error \\
\hline Education level (Year) & $0.565 * * *$ & 0.203 \\
\hline Household size & $0.673^{*}$ & 0.383 \\
\hline Farming experience (Year) & $-0.389 * *$ & 0.152 \\
\hline Gender $(1=$ male $; 0=$ female $)$ & 1.504 & 1.417 \\
\hline Access to credit $(Y e s=1, N o=0)$ & $5.686^{* * * *}$ & 1.695 \\
\hline Coop. membership $(Y e s=1, N o=0)$ & $3.255 * * *$ & 1.119 \\
\hline Age (Year) & -0.104 & 0.067 \\
\hline \multicolumn{3}{|l|}{$-2 \log$ Likelihood $=31.807$} \\
\hline \multicolumn{3}{|l|}{ Chi-Square $=103.590 * * *$} \\
\hline \multicolumn{3}{|l|}{ Nagelkerke $\mathrm{R}^{-2}=0.866$} \\
\hline Sample size $=104$ & & \\
\hline
\end{tabular}

\section{Conclusion}

The study has shown that livelihood diversification among poultry farmers is prevalent in order to cope with risks. Among the factors influencing diversification status at household level, education of head plays a positive and significant role. Household size, access to credit and cooperative society's participation also play positive significant roles in adopting multiple means of livelihood. Policies that would remove the identified constraints to diversification and widen its possibilities are generally encouraged. Better credit accessibility and cooperative society participation should be encouraged as these tend to increase the income of the poor households in the area.

\section{References}

Adekunle, A.O., Adegbite, D.A. and Fakayode, and S.B. (2012). "Rural
Financial Services and Poverty Alleviation: the Roles of the Nigerian Agricultural Cooperative and Rural Development Bank (NACRDB) in Oyo state, Nigeria". Nigerian Journal of Agriculture, Food and Environment. 8(1): 1-9. Available online at www.NJAFE.org

Adugna, E. (2012). "Determinants of Livelihood Diversification in Pastoral Societies of Southern Ethiopia". Journal of Agriculture and Biodiversity Research, 1(3): 43-52

Babatunde R.O. and Qaim, M. (2009). Pattern of income diversification rural Nigeria: determinant and impact Journal of international agriculture 48(4): $305-320$

Babatunde, R.O., Olorunsanya, E.O. Omotesho O.A. and Alabi, B.I. (2007). "Economics of Honey Production in Nigeria: Implications 
for Poverty Reduction and Rural Development". Global Approaches to Extension Practice (GAEP), 3(2) 23-30

Barrett, S. (2001). Non-farm income diversification and household livelihood strategies in rural Africa. Concepts, dynamics and policy implications. Food Policy, 26:315331.

Bayaga, A. (2010). "Multinomial Logistic Regression: Usage and Application in Risk Analysis". Journals of Applied of Quantitative Methods, 5(2): 288-297

Block, S. and Webb, P. (2001): "The Dynamics of Livelihood Diversification in Post-famine, Ethiopia”. Food Policy, 26(4) 33-50.

Ellis, F (2000). The determinants of rural livelihood diversification in developing countries. Journal ofAgricultural Economics, 51(2): 289-302

Ellis, F. (2007). "Survey article: Household Strategies and Rural Livelihood Diversification". School of Development Studies, University of East Anglia, Norwich, UK.

FAO (2007). "Poultry in the 21st Century: Avian Influenza and Beyond". (eds)Proceedings of the International Poultry Conference, held 5-7th November 2007, Bangkok, Thailand. Available at: www.fao.org/againfo/reSources/en/p ubs_aprod.html

Gueye, E.F. (2009). "The Role of Networks in Information Dissemination to Family Poultry Farmers". World's Poultry Science Journal, 65: 115-116

Idowu A.O., Adesimi, B. and Akerele, O.E. (2011a). "Non-farm Activities and Poverty among Rural Farm Households in Yewa Division of
Ogun State". J. Soc. Sci., 26(3): 217224.

Idowu, A.O., Awoyemi, T.T., Omonona, B.T. and Falusi, A.O. (2011b). "NonFarm Income Diversification and Poverty among Rural Farm Households in Southwest Nigeria". European Journal of Social Sciences 21(1): 163-178

Ikheloa, E.E. and Inedia, G. (2005). "Analysis of Survival Rate of Chicks in Poultry Farms in Edo State Nigeria" (eds) Proceedings of $39^{\text {th }}$ Annual Conference of the Agricultural Society of Nigeria, University of Benin, Benin City, Nigeria, October $9^{\text {th }}-13^{\text {th }}$ 2005. Pp 43-47.

Ironkwe, M.O. and Ajayi, F.O. (2007): "Profitability Analysis of Broiler Production in Oyibo Local Government Area of River State Nigeria". Global Journal of Agricultural Science, 6 (2): 196-199

Islam, N. (1997). "The non-farm sector and rural development". Food, Agriculture and Environment Discussion Paper No. 22. Washington DC: IFPRI

Kazybayeva, S., Otte, J. and Roland-Holst, D. (2006). "Livestock Production and Household Income Patterns in Rural Senegal". Pro-Poor Livestock Policy Facility Food and Agriculture Organization - Animal Production and Health Division Vialedelle Terme di Caracalla Rome, Italy available at: http://www.fao.org/ag/pplpi.html

LID (Livestock in Development). (1999): "Livestock in Poverty-focused Development". LID, Crewkerne, Somerset, UK

Lipton, M. (2005). "Can Small Farms Survive, Prosper, or be the Key Channel to Cut Mass Poverty?" 
Presentation to FAO Symposiums on Agricultural Commercialization and the Small Farmer, Rome, 4-5 May 2005.

National Population Commission (NPC), (2006). Nigeria National Census of 2006. Available on www.npc.gov.ng

Nouala,S.; Pica-Ciamarra, U. Otte, J. and N'guetta, A. (2011): "Investing in Livestock to Drive Economic Growth in Africa: Rationales and Priorities" available at:www.alive-online.org

Oluwatayo, I.B. (2009). "Poverty and income Diversification among Households in Rural Nigeria: A Gender Analysis of Livelihood Patterns". A Paper Presented at the 2nd Instituto de EstudosSociais e Económicos (IESE) Conference on 'Dynamics of Poverty and Patterns of Economic Accumulation in Mozambique' held in Maputo, Mozambique 22-23 April, 2009.

Omilola, B. (2009). "Rural Non-farm Income and Inequality in Nigeria". IFPRI Discussion Paper No 00899. Available

on www.ifpri.org/pubs/otherpubs.htm\#d $\mathrm{p}$

Poulton, C., Dorward, A. and Kydd, J. (2005). "The Future of Small Farms: New Directions for Services, Institutions and Intermediation". In Proceedings of Research Workshop on the future of small farms Wye, Uk Organized by International Food policy research institute (IFPRI)/2020 initiative and Overseas
Development Institute (ODI) Imperial College, London

Randolph, T.F., Schelling, E. Grace, D. Nicholson, C.F., Leroy, J.L., Cole, D.C., Demment, M.W., Omore, A., Zinsstag, J. and Ruel, M. (2007). "Role of Livestock in Human Nutrition and Health for Poverty Reduction in Developing Countries". The Journal of Animal Science, 10 (85): 2788-2800

Reardon, T. (1997). "Using evidence of household income diversification to inform study of the rural nonfarm labor market in Africa". World Development, 25(5): 735-748

Reardon, T., Berdeque, J. and Escobar, G. (2001). "Rural non-farm employment and incomes in Latin America: Overview and policy implications". World Development, 29(3): 395-409.

Rudie, I. (1995). "The significance of eating, cooperation, support and reputation in Kelantan Malay households". World Development, 27(2): 415-422.

Scoones I. (1998). "Sustainable Rural Livelihoods a Framework for Analysis" IDS working paper No. 72.

Spencer, D. (2002). "The future of Agriculture in Sub-Saharan Africa and South Asia". In Sustainable Food Security for All by 2020.Proceedings of an International Conference, September 4-6, 2001, Bonn, Germany. IFPRI, Washington, D.C.

World Bank (1999). World Bank Development Indicator. Washington, DC: The World Bank. 